REPORTING WAR 

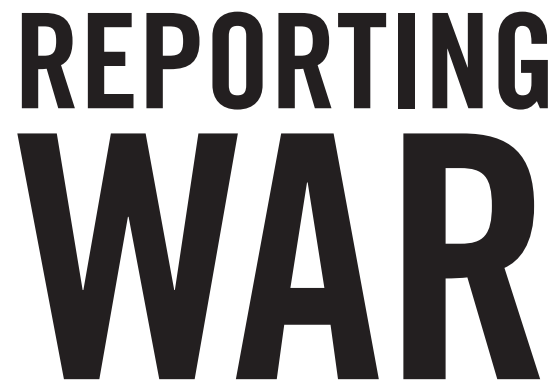

HOW FOREIGN CORRESPONDENTS

RISKED CAPTURE, TORTURE AND DEATH TO COVER WORLD WAR II

\section{RAY MOSELEY}

YALE UNIVERSITY PRESS

NEW HAVEN AND LONDON 


\section{Copyright @ 2017 Ray Moseley}

All rights reserved. This book may not be reproduced in whole or in part, in any form (beyond that copying permitted by Sections 107 and 108 of the U.S. Copyright Law and except by reviewers for the public press) without written permission from the publishers.

For information about this and other Yale University Press publications, please contact: U.S. Office: sales.press@yale.edu yalebooks.com

Europe Office: sales@yaleup.co.uk yalebooks.co.uk

Typeset in Adobe Garamond Pro by IDSUK (DataConnection) Ltd

Printed in Great Britain by Gomer Press Ltd, Llandysul, Ceredigion, Wales

Library of Congress Cataloging-in-Publication Data

Names: Moseley, Ray, 1932- author.

Title: Reporting war : how foreign correspondents risked capture, torture, and death to cover World War II / Ray Moseley.

Other titles: How foreign correspondents risked capture, torture and death to cover World War II

Description: New Haven : Yale University Press, [2017] | Includes bibliographical references and index.

Identifiers: LCCN 2016036163 | ISBN 9780300224665 (alk. paper)

Subjects: LCSH: World War, 1939-1945-Press coverage. | World War, 1939-1945-Journalists. | War correspondents-History-20th century. | World War, 1939-1945-Radio broadcasting and the war. | World War, 1939-1945-Mass media and the war.

Classification: LCC D798 .M67 2017 | DDC 070.4/4994053—dc23

LC record available at https://lccn.loc.gov/2016036163

A catalogue record for this book is available from the British Library.

1098776543321 
For Caspar, Hugo and Thomas

with love

Grandpa aka Gramps 
